\title{
ISESEuroSun 2016
}

\section{A set of key performance indicators for solar heating and cooling systems}

\author{
Marco Beccali ${ }^{1}$, Maurizio Cellura ${ }^{1}$, Sonia Longo ${ }^{1}$ and Daniel Mugnier ${ }^{2}$ \\ ${ }^{1}$ University of Palermo - Department of Energy, Information Engineering and Mathematical Models, \\ Palermo (Italy) \\ ${ }^{2}$ Tecsol, Perpignan Cedex (France)
}

\begin{abstract}
The application of solar heating and cooling systems for building air-conditioning actually shows a significant potential of exploitation, particularly in sunny regions. The choice whether or not to apply such technologies in different climates should be based on the assessment of their energy/environmental, economic and social sustainability, as well as their technical characteristics as reliability, durability and energy efficiency. To support researchers and decision-makers in the selection of the best solar air-conditioning solution in a specific geographic and energy context, the paper proposes a set of technical, economic, energy/environmental and social key performance indicators. The research activity was developed within the Task 53 "New generation solar cooling \& heating systems (PV or solar thermally driven systems)" of the International Energy Agency.
\end{abstract}

Keywords: Solar heating and cooling, sustainability, key performance indicators, energy

\section{Introduction}

The selection of the best performing solar heating and cooling (SHC) system for satisfying the cooling and heating demand of buildings in a specific location is a complex task (Beccali et al., 2012; 2014; 2016), which has to include different assessment criteria (costs, environmental impacts, etc.). This is particularly relevant for the assessment of new generation technologies, which need to be carefully evaluated for their subsequent inclusion in the market.

This topic was investigated within the International Energy Agency SHC Programme - Task 53 "New generation solar cooling \& heating systems (PV or solar thermally driven systems)" aiming to the definition of a set of key performance indicators (KPIs) (Mugnier, 2013), which can be useful for helping researchers and decision-makers to have a complete overview of the performance of different SHC technologies.

\section{A set of key performance indicators for solar heating and cooling systems}

The set of KPIs is based on a multi-disciplinary approach that takes into account the three pillars of sustainability: environmental (including energy), economic and social sustainability (Ardente et al., 2016; Sala et al., 2015). Furthermore, a fourth element is added, describing the technical performance of the SHC technology.

In all, the set includes 19 KPIs, each of which is synthesized by using an "ad hoc" format, including the following sections:

- KPI name: it indicates the name of the KPI and its acronym.

- Typology: it specifies if the KPI is an economic, energy, environmental, social or technical indicator.

- Type of assessment: it clarifies the qualitative or quantitative nature of the indicator.

- Unit of measure: only for quantitative KPIs.

- Description: it includes a brief description of the indicator.

- Performance target: it defines the target to be achieved for improving the performance of the system under investigation for the selected KPI. 
- Measurement process: it describes the process or the methodology used for measuring the value of the indicator.

In detail, the following KPIs where identified for describing the SHC systems:

- Energy KPIs: global energy requirement (Table 1), energy payback time (Table 2), energy return ratio (Table 3).

- Environmental KPIs: global warming potential (Table 4), acidification potential (Table 5), eutrophication potential (Table 6), ozone depletion potential (Table 7), photochemical ozone creation potential (Table 8), GWP payback time (Table 9).

- Economic indicators: money savings during the operation (Table 10), initial cost ratio (Table 11), operation/maintenance costs ratio (Table 12), payback period (Table 13).

- Social indicators: customer satisfaction (Table 14), ease of use of the system (Table 15).

- Technical indicators: useful life of the system (Table 16), thermal performance coefficient of the ab/adsorption machine (Table 17), electrical COP (Table 18), reliability of the system (Table 19)..

Tab. 1: Energy KPI: Global Energy Requirement

\begin{tabular}{|c|c|}
\hline KPI name & Global Energy Requirement (GER) \\
\hline Typology & Energy indicator \\
\hline Type of assessment & Quantitative \\
\hline Unit of measure & MJ \\
\hline Description & $\begin{array}{l}\text { GER represents the entire (renewable and non-renewable) energy demand, valued } \\
\text { as primary energy, which arises in connection with the production, use and } \\
\text { disposal of an economic good (product or service). }\end{array}$ \\
\hline Performance target & $\begin{array}{l}\text { Percentage reduction of GER during the life cycle of the system (to be fixed case } \\
\text { by case). }\end{array}$ \\
\hline Measurement process & $\begin{array}{l}\text { The KPI can be calculated following a life cycle approach with the formula: } \\
G E R=G E R_{M}+G E R_{U}+G E R_{R D} \text { (eq.1). } \\
G^{-} R_{M} \text { is the primary energy consumed during the manufacture (including energy } \\
\text { and raw materials supply) of a product or a service; } \\
G^{G E R_{U}} \text { is the primary energy consumed during the use of a product or a service; } \\
G_{\mathrm{RD}} \text { is the primary energy consumed during the end-of-life of a product or a } \\
\text { service (recycling or disposal). }\end{array}$ \\
\hline
\end{tabular}

Tab. 2: Energy KPI: Energy Payback Time

\begin{tabular}{|c|c|}
\hline KPI name & Energy Payback Time (EPT) \\
\hline Typology & Energy indicator \\
\hline Type of assessment & Quantitative \\
\hline Unit of measure & Years \\
\hline Description & $\begin{array}{l}\text { EPT is defined as the time during which the SHC system must work to harvest the } \\
\text { additional primary energy required for its manufacturing and end-of-life, if } \\
\text { compared with a conventional system. The harvested energy is considered as net } \\
\text { of the energy expenditure for the system operation. }\end{array}$ \\
\hline Performance target & EPT lower than the useful life of the system \\
\hline Measurement process & $\begin{array}{l}\text { The KPI can be calculated with the formula: } \\
\text { EPT }=\left(G E R_{\text {SHC-system }}-G E R_{\text {Conventioral-system }}\right) / E_{\text {year }} \text { (eq.2). } \\
\text { GER }_{\text {SHC-system }} \text { is the GER related to the life cycle of the SHC system except for the } \\
\text { operation phase; } \\
\text { GER }_{\text {Conventional-system is the GER related to the life cycle of the conventional system }} \text { except for the operation phase; } \\
\mathrm{E}_{\text {year }} \text { is the net yearly primary energy saving due to the use of the SHC system in } \\
\text { replacement of a conventional one. }\end{array}$ \\
\hline
\end{tabular}


Tab. 3: Energy KPI: Energy Return Ratio

\begin{tabular}{|c|c|}
\hline KPI name & Energy Return Ratio (ERR) \\
\hline Typology & Energy indicator \\
\hline Type of assessment & Quantitative \\
\hline Unit of measure & - \\
\hline Description & $\begin{array}{l}\text { ERR represents how many times the energy saving overcomes the primary energy } \\
\text { consumed during the manufacturing and the end-of-life of the SHC system. }\end{array}$ \\
\hline Performance target & N.A. \\
\hline Measurement process & $\begin{array}{l}\text { The KPI can be calculated with the formula: } \\
E R R=E_{\text {overall }} / G E R_{\text {SHC-system }} \text { (eq.3). } \\
\text { GER }_{\text {SHC-system }} \text { is the GER related to the life cycle of the SHC system except for the } \\
\text { operation phase; } \\
\mathrm{E}_{\text {overall }} \text { is the net primary energy saving during the overall lifetime of the SHC } \\
\text { system. }\end{array}$ \\
\hline
\end{tabular}

Tab. 4: Environmental KPI: Global Warming Potential

\begin{tabular}{|c|c|}
\hline KPI name & Global Warming Potential (GWP) \\
\hline Typology & Environmental indicator \\
\hline Type of assessment & Quantitative \\
\hline Unit of measure & $\mathrm{kg} \mathrm{CO} 2 \mathrm{eq}$ \\
\hline Description & $\begin{array}{l}\text { GWP is a measure of the relative, globally averaged, warming effect arising from } \\
\text { the emissions of a particular greenhouse-gas. The GWP represents the time- } \\
\text { integrated commitment to climate forcing from the instantaneous release of } 1 \mathrm{~kg} \\
\text { of a trace gas expressed relative to that from } 1 \mathrm{~kg} \text { of carbon dioxide. }\end{array}$ \\
\hline Performance target & $\begin{array}{l}\text { Percentage reduction of GWP during the life cycle of the system (to be fixed case } \\
\text { by case). }\end{array}$ \\
\hline Measurement process & $\begin{array}{l}\text { The KPI can be calculated following a life cycle approach with the formula: } \\
G W P=\sum_{1}^{n}\left(m_{i} * C F_{i}\right) \text { (eq.4). } \\
\qquad \mathrm{m}_{i} \text { is the mass of the substance } i \text { emitted; } \\
\mathrm{CF}_{i} \text { is the characterization factor that reflects the relative contribution of the } \\
\text { substance } i \text { to the impact on GWP. }\end{array}$ \\
\hline
\end{tabular}

Tab. 5: Environmental KPI: Acidification Potential

\begin{tabular}{|c|c|}
\hline KPI name & Acidification Potential (AP) \\
\hline Typology & Environmental indicator \\
\hline Type of assessment & Quantitative \\
\hline Unit of measure & $\mathrm{kg} \mathrm{SO} \mathrm{Seq}$ \\
\hline Description & $\begin{array}{c}\text { AP measures the impact generated by the emission of airborne acidifying } \\
\text { substances (as nitrogen oxides and sulphur dioxide). Acidification refers literally } \\
\text { to processes that increase the acidity of water and soil systems by hydrogen ion } \\
\text { concentration. }\end{array}$ \\
\hline Performance target & $\begin{array}{l}\text { Percentage reduction of AP during the life cycle of the system (to be fixed case by } \\
\text { case). }\end{array}$ \\
\hline Measurement process & $\begin{array}{l}\text { The KPI can be calculated following a life cycle approach with the formula: } \\
A P=\sum_{1}^{n}\left(m_{i} * C F_{i}\right) \text { (eq.5). } \\
\qquad \mathrm{m}_{i} \text { is the mass of the substance } i \text { emitted; } \\
\mathrm{CF}_{i} \text { is the characterization factor that reflects the relative contribution of the } \\
\text { substance } i \text { to the impact on AP. }\end{array}$ \\
\hline
\end{tabular}


Tab. 6: Environmental KPI: Eutrophication Potential

\begin{tabular}{|c|c|}
\hline KPI name & Eutrophication Potential (EP) \\
\hline Typology & Environmental indicator \\
\hline Type of assessment & $\begin{array}{c}\text { Quantitative } \\
\mathrm{kg} \mathrm{PO}_{4}{ }^{3-} \text { eq }\end{array}$ \\
\hline Unit of measure & $\begin{array}{c}\text { EP is defined as the potential of nutrients to cause over-fertilization of water and } \\
\text { soil which in turn can result in increased growth of biomass. For example, it } \\
\text { causes excessive plant growth like algae in rivers which causes severe reductions } \\
\text { in water quality and animal populations. }\end{array}$ \\
\hline Performance target & $\begin{array}{c}\text { Percentage reduction of EP during the life cycle of the system (to be fixed case by } \\
\text { case). }\end{array}$ \\
\hline Measurement process & $\begin{array}{c}\text { The KPI can be calculated following a life cycle approach with the formula: } \\
\mathrm{CF}_{i} \text { is the characterization factor that reflects the relative contribution of the } \\
\text { substance } i \text { to the impact on EP. }\end{array}$ \\
\hline
\end{tabular}

Tab. 7: Environmental KPI: Ozone Depletion Potential

\begin{tabular}{|c|c|}
\hline KPI name & Ozone Depletion Potential (ODP) \\
\hline Typology & Environmental indicator \\
\hline Type of assessment & Quantitative \\
\hline Unit of measure & kg CFC-1 $1_{\mathrm{eq}}$ \\
\hline Description & $\begin{array}{c}\text { ODP indicates the potential for emissions of chlorofluorocarbon compounds and } \\
\text { other halogenated hydrocarbons to deplete the ozone layer in the stratosphere, } \\
\text { where it shields the earth from harmful ultraviolet radiation. }\end{array}$ \\
\hline Performance target & $\begin{array}{c}\text { Percentage reduction of ODP during the life cycle of the system (to be fixed case } \\
\text { by case). }\end{array}$ \\
\hline Measurement process & $\begin{array}{c}\text { The KPI can be calculated following a life cycle approach with the formula: } \\
O D P=\sum_{1}^{n}\left(m_{i} * C F_{i}\right) \text { (eq.7). } \\
\mathrm{m}_{i} \text { is the mass of the substance } i \text { emitted; } \\
\mathrm{CF}_{i} \text { is the characterization factor that reflects the relative contribution of the } \\
\text { substance } i \text { to the impact on ODP. }\end{array}$ \\
\hline
\end{tabular}

Tab. 8: Environmental KPI: Photochemical Ozone Creation Potential

\begin{tabular}{|c|c|}
\hline KPI name & Photochemical Ozone Creation Potential (POCP) \\
\hline Typology & Environmental indicator \\
\hline Type of assessment & $\begin{array}{c}\text { Quantitative } \\
\mathrm{kg} \mathrm{C}_{2} \mathrm{H}_{4 \mathrm{eq}}\end{array}$ \\
\hline Unit of measure & $\begin{array}{c}\text { POCP is related to the potential for volatile organic compounds and oxides of } \\
\text { nitrogen to generate photochemical or summer smog in the presence of heat and } \\
\text { sunlight. }\end{array}$ \\
\hline Description & $\begin{array}{c}\text { Percentage reduction of POCP during the life cycle of the system (to be fixed case } \\
\text { by case). }\end{array}$ \\
\hline Performance target & $\begin{array}{c}\text { The KPI can be calculated following a life cycle approach with the formula: } \\
P O C P=\sum_{1}^{n}\left(m_{i} * C F_{i}\right) \text { (eq.8). } \\
\mathrm{m}_{i} \text { is the mass of the substance } i \text { emitted; } \\
\mathrm{CF}_{i} \text { is the characterization factor that reflects the relative contribution of the } \\
\text { substance } i \text { to the impact on POCP. }\end{array}$ \\
\hline
\end{tabular}


Tab. 9: Environmental KPI: GWP Payback Time

\begin{tabular}{|c|c|}
\hline KPI name & GWP Payback Time (GWP-PT) \\
\hline Typology & Environmental indicator \\
\hline Type of assessment & Quantitative \\
\hline Unit of measure & Years \\
\hline Description & $\begin{array}{l}\text { GWP-PT is defined as the time during which the avoided GWP impact due to the } \\
\text { use of the SHC system in replacement of a conventional system is equal to GWP } \\
\text { impact caused during its manufacturing and end-of-life. }\end{array}$ \\
\hline Performance target & GWP-PT lower than the useful life of the system. \\
\hline Measurement process & 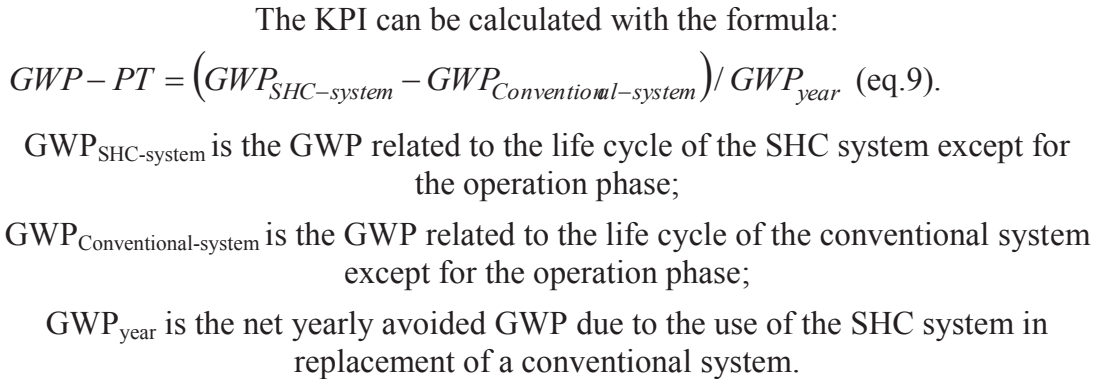 \\
\hline
\end{tabular}

Tab. 10: Economic KPI: Money savings during the operation

\begin{tabular}{|c|c|}
\hline KPI name & Money savings during the operation (MSDO) \\
\hline Typology & Economic indicator \\
\hline Type of assessment & Quantitative \\
\hline Unit of measure & $€$ \\
\hline Description & $\begin{array}{l}\text { MSDO represents the money saving during the useful life of the SHC system due } \\
\text { to its lower energy (electricity and natural gas) consumption if compared with a } \\
\text { conventional system. }\end{array}$ \\
\hline Performance target & $\begin{array}{c}\text { Lower than the cost of energy (electricity and natural gas) consumed by the SHC } \\
\text { system during its useful life. }\end{array}$ \\
\hline Measurement process & 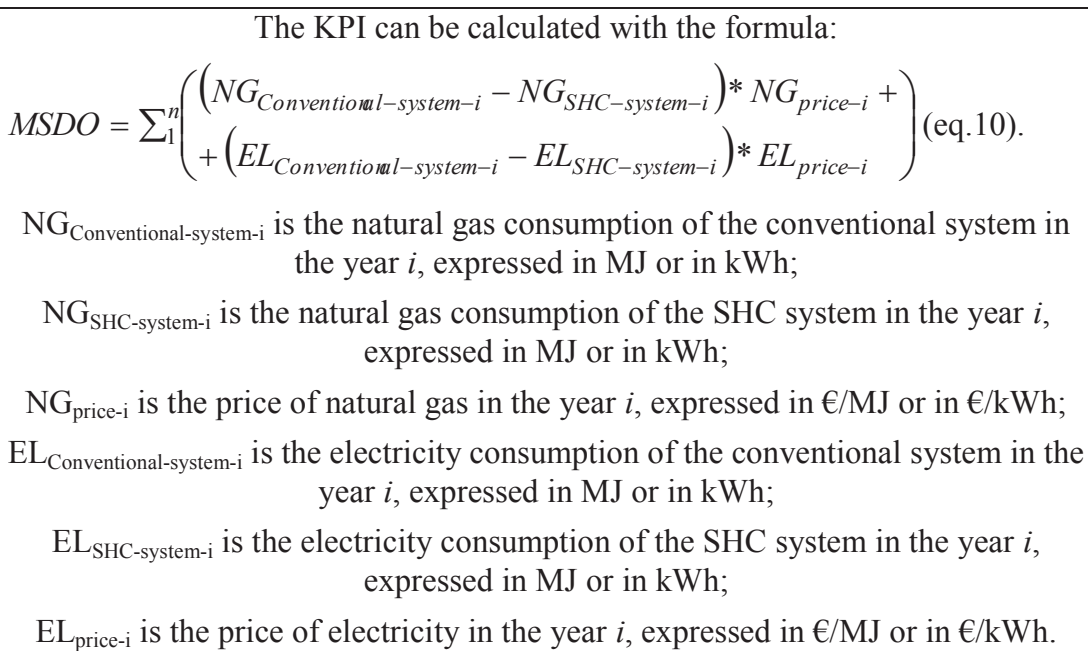 \\
\hline
\end{tabular}


Tab. 11: Economic KPI: Initial cost ratio

\begin{tabular}{|c|c|}
\hline KPI name & Initial cost ratio (ICR) \\
\hline Typology & Economic indicator \\
\hline Type of assessment & Quantitative \\
\hline Unit of measure & - \\
\hline Description & $\begin{array}{l}\text { ICR is the ratio between the price set by supplier/vendor in their price list when } \\
\text { the customer purchases the SHC system from them and the corresponding price of } \\
\text { the conventional system. }\end{array}$ \\
\hline Performance target & Lower than 1 \\
\hline Measurement process & $\begin{array}{l}\text { The KPI can be calculated with the formula: } \\
\text { ICR }=P_{\text {SHC-system }} / P_{\text {Conventioral-system }} \text { (eq.11). } \\
\mathrm{P}_{\mathrm{SHC}-\text { system }} \text { is the price of the } \mathrm{SHC} \text { system defined by the supplier/vendor; } \\
\mathrm{P}_{\text {Conventional-system }} \text { is the price of the conventional system defined by the } \\
\text { supplier/vendor. } \\
\text { Both } \mathrm{P}_{\mathrm{SHC}-\text { system }} \text { and } \mathrm{P}_{\text {Conventional-system }} \text { can be found by the customer in the price list } \\
\text { given by the supplier/vendor. }\end{array}$ \\
\hline
\end{tabular}

Tab. 12: Economic KPI: Operation/maintenance cost ratio

\begin{tabular}{|c|c|}
\hline KPI name & Operation-maintenance cost ratio (OMC) \\
\hline Typology & Economic indicator \\
\hline Type of assessment & Quantitative \\
\hline Unit of measure & - \\
\hline Description & $\begin{array}{l}\text { OMC is the ratio between the cost to the customer during the useful life of the SHC } \\
\text { system for its operation and maintenance (regular maintenance and repair) and the } \\
\text { corresponding cost of the conventional system. }\end{array}$ \\
\hline Performance target & Lower than 1 \\
\hline Measurement process & 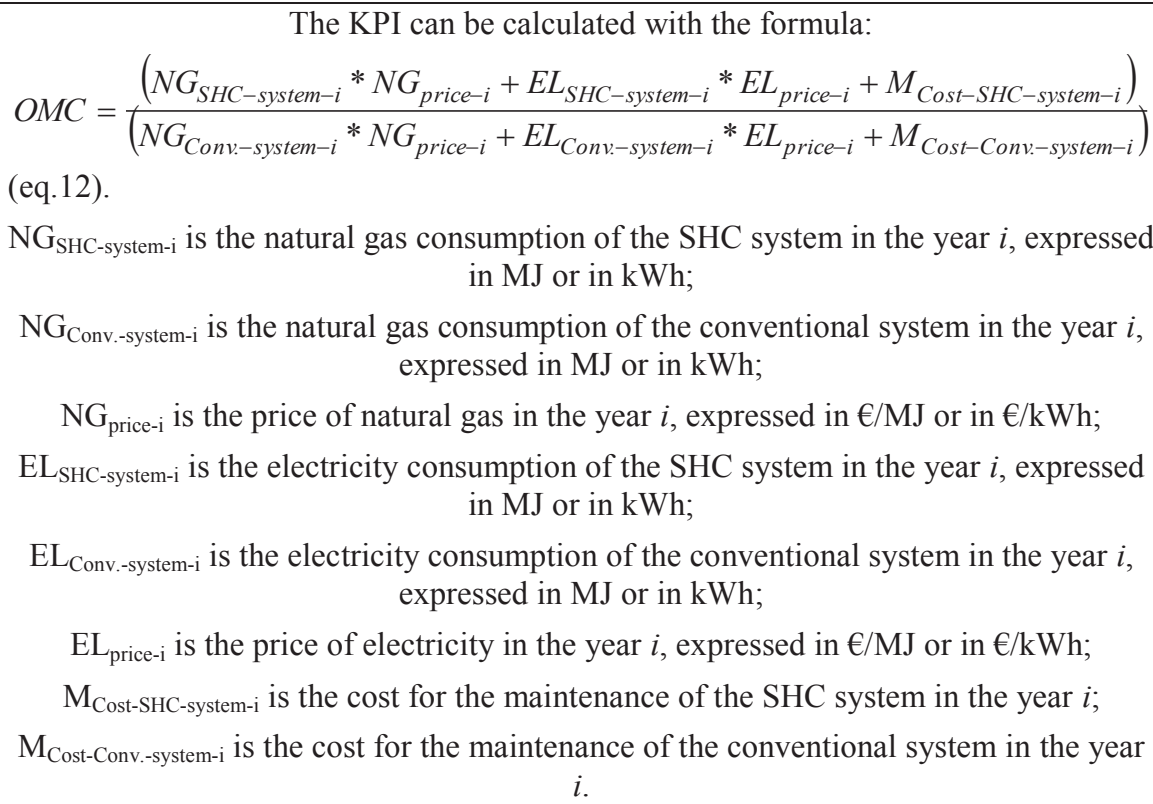 \\
\hline
\end{tabular}

Tab. 13: Economic KPI: Payback period

\begin{tabular}{|c|c|}
\hline KPI name & Payback period (PP) \\
\hline Typology & Economic indicator \\
\hline Type of assessment & Quantitative \\
\hline Unit of measure & \\
\hline Description & PP is the time in which the initial cash outflow of an investment for the SHC \\
\hline
\end{tabular}




\begin{tabular}{|c|c|}
\hline & $\begin{array}{l}\text { system is expected to be recovered from the economic benefit (positive cash flow) } \\
\text { generated by the investment. }\end{array}$ \\
\hline Performance target & PP lower than the useful life of the system \\
\hline Meas & $\begin{array}{l}\text { The formula to calculate the KPI depends on whether the economic benefit } \\
\text { (positive cash flow) per period is even or uneven. } \\
\text { In case it is even, the formula to calculate the KPI period is: } \\
P P=P_{S H C-\text { system }} \text { / } B_{\text {annual }} \text { (eq.13). } \\
\text { P }_{\text {SHC-system is the price of the SHC system defined by the supplier/vendor; }} \text {. } \\
\mathrm{B}_{\text {annual }} \text { is the net annual benefit (positive cash flow) due to the use of the SHC } \\
\text { system in replacement of a conventional one in terms of decrement in expenditure } \\
\text { for electricity and natural gas. } \\
\text { When the economic benefit is uneven, it is needed to calculate the cumulative net } \\
\text { cash flow for each period and then use the following formula for the KPI: } \\
P P=A+B / C \text { (eq.14). } \\
\text { A is the last period with a negative cumulative cash flow; B is the absolute value } \\
\text { of cumulative cash flow at the end of the period A; C is the total cash flow during } \\
\text { the period after A. }\end{array}$ \\
\hline
\end{tabular}

Tab. 14: Social KPI: Customer satisfaction

\begin{tabular}{|c|c|}
\hline KPI name & Customer satisfaction (CS) \\
\hline Typology & Social indicator \\
\hline Type of assessment & Qualitative \\
\hline Unit of measure & N.A. \\
\hline Description & CS indicates how satisfied the client is with the SHC system \\
\hline Performance target & Positive value of CS \\
\hline Measurement process & 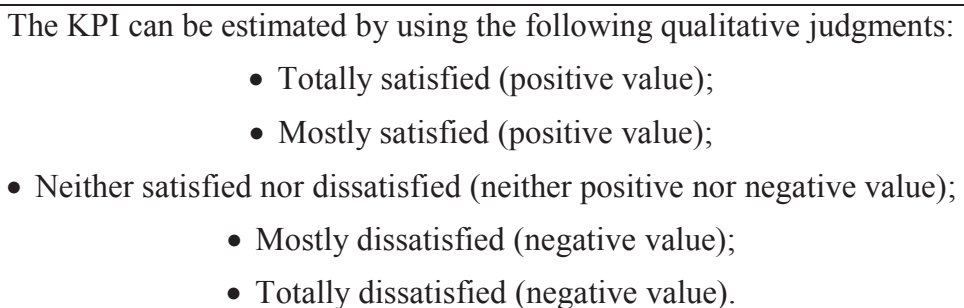 \\
\hline
\end{tabular}

Tab. 15: Social KPI: Ease of use of the system

\begin{tabular}{|c|c|}
\hline KPI name & Ease of use of the system (EUS) \\
\hline Typology & Social indicator \\
\hline Type of assessment & Qualitative \\
\hline Unit of measure & N.A. \\
\hline Description & EUS indicates the ease of use of the SHC system \\
\hline Performance target & Positive value of EUS \\
\hline Measurement process & $\begin{array}{l}\text { The KPI can be estimated by using the following qualitative judgments: } \\
\text { - Very easy to use (positive value); } \\
\text { - Easy enough to use (positive value); } \\
\text { - Neither easy nor difficult to use (neither positive nor negative value); } \\
\text { - Not very easy to use (negative value); } \\
\text { - Not easy to use (negative value). }\end{array}$ \\
\hline
\end{tabular}


Tab. 16: Technical KPI: Useful life of the system

\begin{tabular}{|c|c|}
\hline KPI name & Useful life of the system (ULS) \\
\hline Typology & Technical indicator \\
\hline Type of assessment & Quantitative \\
\hline Unit of measure & Years \\
\hline Description & ULS indicates the period during which the system is expected to be usable for the \\
purpose it was acquired.
\end{tabular}

Tab. 17: Technical KPI: Thermal Performance Coefficient of the ab/adsorption machine (Boudéhenn et al., 2013)

\begin{tabular}{|c|c|}
\hline KPI name & Thermal Performance Coefficient $\left(\mathrm{COP}_{\mathrm{th}}\right)$ of the ab/adsorption machine \\
\hline Typology & Technical indicator \\
\hline Type of assessment & Quantitative \\
\hline Unit of measure & - \\
\hline Description & $\begin{array}{l}\mathrm{COP}_{\text {th }} \text { is the ratio between the thermal cooling energy supplied by the evaporator } \\
\text { and the thermal heat energy supplied to the generator of the sorption machine. }\end{array}$ \\
\hline Performance target & To be fixed case by case \\
\hline Measurement process & 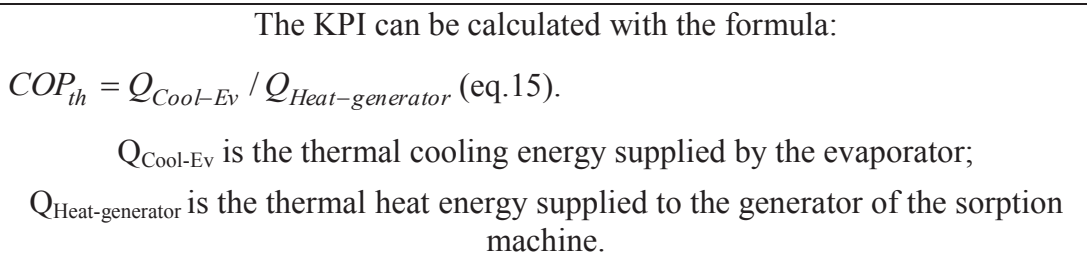 \\
\hline
\end{tabular}

Tab. 18: Technical KPI: Solar Electric Performance Coefficient of the system (Boudéhenn et al., 2013)

\begin{tabular}{|c|c|}
\hline KPI name & Solar Electric Performance Coefficient $\left(\mathrm{COP}_{\text {Elec-sol }}\right)$ of the system \\
\hline Typology & Technical indicator \\
\hline Type of assessment & Quantitative \\
\hline Unit of measure & - \\
\hline Description & $\begin{array}{c}\mathrm{COP}_{\text {Elec-sol }} \text { corresponds to the ratio of the system's useful solar energy to auxiliary } \\
\text { consumption. }\end{array}$ \\
\hline Performance target & To be fixed case by case \\
\hline Measurement process & $\begin{array}{l}\text { The KPI can be calculated with the formula: } \\
C O P_{\text {Elec-sol }}=E S U / E_{\text {Aux-sol }} \text { (eq.16). } \\
\text { ESU refers to the thermal solar energy exploited by the system integrating thermal } \\
\text { losses from hot and cold storage; } \\
\mathrm{E}_{\text {Aux-sol }} \text { Electricity consumption of the solar system auxiliaries. }\end{array}$ \\
\hline
\end{tabular}


Tab. 19: Technical KPI: Reliability of the system

\begin{tabular}{|c|c|}
\hline KPI name & Reliability of the system (RS) \\
\hline Typology & Technical indicator \\
\hline Type of assessment & Quantitative \\
\hline Unit of measure & $\begin{array}{r}\text { RS at time } t \text { is the probability that the system will perform its function without } \\
\text { failure under stated conditions in the interval }[0, t) .\end{array}$ \\
\hline Description & \multicolumn{2}{c|}{$\begin{array}{c}\text { RS higher than } 90 \% \\
\text { Performance target }\end{array}$} \\
\hline Measurement process & $\begin{array}{c}R S(t)=P(X>t) \text { (eq.17). } \\
\mathrm{X} \text { is a random variable that represents the time to occurrence of system failure. }\end{array}$ \\
\hline
\end{tabular}

\section{Conclusions}

A complete evaluation of SHC systems should be based on the assessment of their economic, energy/environmental and social sustainability, as well as their technical characteristics.

The proposed set of KPIs gives a complete picture of the SHC system, aimed at measuring different aspects of its sustainability and technical performance. It can be useful for enabling researchers and decision-makers to take sustainably-based decisions in the field of SHC technologies, starting from a comprehensive investigation of the technical, economic, energy/environmental and social performance of the systems along their life cycle.

\section{References}

Ardente, F., Cellura, M., Longo, S., Mistretta, M. 2016. Life Cycle Assessment of Solar Technologies, in Dewulf, J., De Meester, S., Alvarenga, R. (Eds.), Sustainability Assessment of Renewables-Based Products: Methods and Case Studies. Wiley, pp. 241-258.

Beccali, M., Cellura, M., Longo, S., Nocke, B., Finocchiaro, P., 2012. LCA of a solar heating and cooling system equipped with a small water-ammonia absorption chiller. Solar Energy 86, 1491-1503.

Beccali, M., Cellura, M., Finocchiaro, P., Guarino, F., Longo, S., Nocke, B., 2014. Life Cycle performance assessment of small solar thermal cooling systems and conventional plants assisted with photovoltaics. Solar Energy 104, 93-102.

Beccali, M., Cellura, M., Longo, S., Guarino, F., 2016. Solar heating and cooling systems versus conventional systems assisted by photovoltaic: Application of a simplified LCA tool. Solar Energy Materials and Solar Cells $156,92-100$.

Boudéhenn, F., Hands, S., White, S., Zahler, C., Gammoh, F., 2013. Task 48 - Deliverable M-C4.3 - Final report Measurement and Verification Procedures, http://task48.iea-shc.org/.

Mugnier, D., 2013. Task 53 New generation solar cooling \& heating systems (PV or solar thermally driven systems) - Task description and Work plan, http://task53.iea-shc.org/.

Sala, S., Ciuffo, B., Nijkamp, P., A systemic framework for sustainability assessment. Ecological Economics $119,314-325$. 